\title{
LIDERANCCAS INDÍGENAS E A LUTA PELA TERRA COMO EXPRESSẢO DA ORGANIZAÇÃO SOCIOPOLÍTICA GUARANI E KAIOWÁ
}

THIAGO LEANDRO VIEIRA CAVALCANTE ${ }^{1}$

$U F G D$

\begin{abstract}
RESUMO: Com base em dados históricos e etnográficos obtidos em terras indígenas guarani e kaiowá na região sul do Estado de Mato Grosso do Sul entre os anos de 2009 e 2014, o artigo propõe uma discussão sobre as formas tradicionais de liderança entre os povos Kaiowá e Guarani e a capitania, modelo imposto pelo Serviço de Proteção ao Índio. A pesquisa demonstra que a inviabilização da manutenção das relações sociopolíticas tradicionais no interior das reservas indígenas impulsiona movimentos de retomada de frações de terras de ocupação tradicional indígena. Por sua vez, tais retomadas possibilitam o restabelecimento, ainda que em condições precárias, da organização sociopolítica, oportunizando, assim, a constituição de novas famílias extensas e de novos tekoha.
\end{abstract}

PALAVRAS-CHAVE: capitania; liderança indígena; retomadas de terras indígenas; guarani; kaiowá.

ABSTRACT: Based on historical and ethnographic data obtained in guarani and kaiowá indigenous lands in southern state of Mato Grosso do Sul between 2009 and 2014, this paper proposes a discussion about the traditional forms of leadership between the Kaiowa and Guarani and the captaincy model imposed by the Serviço de Proteção ao Índio - SPI (Indian Protection Service). The research shows that the impracticability of maintaining traditional socio-political relations within the indigenous reserves drives traditional lands retake movements. These retake moements enable the restoration, although in poor conditions, of the socio-political organization, thus providing opportunities for the creation of new extended families and new "tekoha".

KEYWORDS: captaincy; indigenous leadership; retake of indigenous lands; guarani; kaiowá.

\footnotetext{
${ }^{1}$ É graduado (UEL, 2004), mestre (UFGD, 2009) e doutor (UNESP/Assis, 2013) em História. Atua como professor de graduação e pós-graduação (mestrado e doutorado) em História na UFGD. É pesquisador da cátedra UNESCO/UFGD "Diversidade Cultural, Gênero e Fronteiras". E-mail: thiagocavalcante@ufgd.edu.br
} 


\section{Introdução}

Os Kaiowá e os Guarani² são dois povos indígenas, etnicamente diferenciados, porém culturalmente muito próximos. Ambos têm boa parte de seu território de ocupação tradicional localizada na região sul do atual Estado de Mato Grosso do Sul, região de notório interesse para o agronegócio exportador brasileiro.

Sua história, em especial a de seu processo de esbulho territorial, já é razoavelmente bem conhecida em diferentes escalas de análise por meio de vários trabalhos históricos e antropológicos, dentre outros: $O$ confinamento e o seu impacto sobre os Pai-Kaiowá (1993) e O impacto da perda da terra sobre a tradição Kaiowa/Guarani: os difíceis caminhos da Palavra (1997), ambos de Antonio Brand; Nande Ru Marangatu. Laudo antropológico e histórico sobre uma terra kaiowa na fronteira do Brasil com o Paraguai, município de Antônio João, Mato Grosso do Sul, de Jorge Eremites de Oliveira e Levi Marques Pereira (2009); e a tese de minha autoria intitulada Colonialismo, Território e Territorialidade: a luta pela terra dos Guarani e Kaiowá em Mato Grosso do Sul (CAVALCANTE, 2013).

Com suas particularidades e especificidades, cada um desses trabalhos apresenta informações que indicam que a presença dos povos Guarani e Kaiowá nessa região do continente americano remonta a antes do início da colonização europeia. Os autores apontam que, nessa região, tais povos só vieram a sofrer consequências de grandes proporções do processo de colonização no século XIX especialmente após o término do conflito bélico que contrapôs o Brasil, a Argentina e o Uruguai, que formaram a Tríplice Aliança, ao Paraguai (1864-1870).

Findada a guerra e estabelecidas as fronteiras nacionais, o Estado brasileiro iniciou um processo de estímulo da ocupação não indígena da região, processo esse que, com diferentes matizes, perdurou até a segunda metade do século XX. Ao longo do período que vai do final do século XIX até os dias atuais, tal processo foi responsável por diversas formas de ocupação, colonização e uso econômico das terras dessa

\footnotetext{
2 A grafia de nomes indígenas segue o padrão estabelecido por convenção assinada na $1^{\mathrm{a}}$ Reunião Brasileira de Antropologia, realizada em 1953, na cidade do Rio de Janeiro. Os nomes não recebem flexão de número ou de gênero e são escritos com iniciais maiúsculas. Nos casos em que os nomes são usados como adjetivos mantêm-se o padrão de não flexão, mas utilizam-se iniciais minúsculas.
} 
região, tal diversidade pode ser verificada na bibliografia supracitada. $\mathrm{O}$ que elas têm em comum é o fato de terem contribuído diretamente para o esbulho das terras de ocupação tradicional guarani e kaiowá.

Nesse contexto, merece destaque a atuação do Serviço de Proteção aos Índios (SPI), órgão criado em 1910 e que desde o seu início teve ampla atuação entre os Guarani e Kaiowá. Sua principal medida fundiária foi a criação de oito pequenas reservas indígenas destinadas aos Guarani e Kaiowá, sendo a menor delas com 668 hectares e a maior com 3.594 hectares, todas atualmente com superpopulação, incontáveis problemas sociais e graves violações de direitos humanos (CAVALCANTE, 2013, p. 84-94; DHESCA, 2014).

As reservas indígenas serviram como espaço para aglutinação de diversas famílias extensas que para lá eram levadas ou induzidas a ir, liberando, assim, seu vasto território para a colonização. O processo de esbulho ocorreu em diferentes períodos de acordo com cada região do estado. No entanto, já no final dos anos 1970, a situação no interior das reservas indígenas passou a ser bastante complicada, tanto do ponto de vista sociopolítico quanto no que diz respeito à economia de subsistência e reciprocidade, isso motivou o desencadeamento de movimentos reivindicatórios pela demarcação das terras indígenas de ocupação tradicional. Algumas pequenas terras indígenas foram demarcadas nas décadas de 1980, 1990 e 2000, mas isso não foi suficiente para aliviar as tensões existentes, ao contrário disso, nessas décadas as tensões ampliaram-se em escala geométrica. Tal ampliação se deve ao fato de que as medidas tomadas pelo Estado sempre foram pontuais, jamais estruturais (CAVALCANTE, 2013).

Diante disso, da resistência dos setores ruralistas da sociedade e da inércia do Estado brasileiro na realização de seu dever constitucional de demarcar as terras indígenas (Cf. Art. 231 da Constituição Federal de 1988), o clima na região é de permanente disputa em torno do apoio ou da negação da necessidade da demarcação das terras de ocupação tradicional guarani e kaiowá. É nesse cenário que se dão as análises aqui propostas.

Formas de organização sociopolítica guarani e kaiowá 
Estudos antropológicos apontam que a família extensa é uma das principais unidades sociopolíticas entre os Guarani e Kaiowá. No antigo sistema de lideranças, a figura principal era o chefe de parentela o hi'u ou tamõi (avô), configuração que em boa medida se mantém na atualidade. Frequentemente, o chefe de parentela também é um rezador (SUSNIK, 1979-1980; PEREIRA, 2004).

O tekoha ${ }^{3}$, unidade sociológica que pode reunir várias famílias extensas, articula-se em torno da figura de um prestigiado líder político e/ou religioso. Esse líder tem a capacidade de reunir em torno de si um significativo número de núcleos residenciais de parentelas (PEREIRA, 2004).

Ao analisar fontes jesuíticas da Província do Paraguai (séc. XVII), Ítala Becker (1992) aponta que os líderes guarani tinham atribuições civis (caciques) e/ou religiosas (pajés). Normalmente, os caciques tiveram uma atitude de aliança com os colonizadores, mas também de recusa e guerra, dependendo do contexto. Já os pajés, quase sempre foram contrários a qualquer aproximação aos colonizadores e foram retratados como os guardiões da tradição indígena, representação condizente inclusive com os rezadores da atualidade (BECKER, 1992, p. 21-54; CAVALCANTE, 2009).

Dificilmente um cacique teria grande prestígio se também não fosse um importante líder religioso; entretanto, nem todo líder religioso era um grande líder civil, ou seja, um organizador da vida cotidiana. Apesar disso, o pajé, mesmo não sendo "oficialmente" liderança civil, de fato podia ter mais autoridade do que um cacique (BECKER, 1992, p. 45).

A liderança desses caciques não parece exclusivamente política, social e econômica, mas também religiosa, motivo por que freqüentemente eles são apresentados como caciques e pajés, feiticeiros ou magos [...] Seria difícil dizer hoje se o líder político teria de ser necessariamente um grande pajé, ou se esta ligação manifesta simplesmente a integração da cultura

\footnotetext{
${ }^{3}$ Tekoha também é uma categoria muito utilizada pelos Guarani e Kaiowá para se referirem a uma porção específica de seu território de ocupação tradicional, a rigor um especo ideal para a territorialização da unidade social que alguns antropólogos também classificam como tekoha. Há um longo debate em torno dos significados e das aplicações do conceito, ver mais detalhes em Cavalcante (2013, p. 75-84).
} 
indígena, onde o aspecto religioso era muito importante e o cacique era o seu mais alto representante (BECKER, 1992, p. 30).

Várias são as denominações dadas a quem exercia as funções de intermediar o homem com as forças consideradas sobrenaturais: feiticeiro ou mago para os jesuítas, pajé para os índios. Modernamente o termo siberiano xamã os substituiu.

Qualquer que seja o termo que usemos para o intermediador, ele era um pensador da cultura e, ao tempo da missão, o mais ferrenho defensor dessa cultura indígena. Podia ser cacique ou não [...] Para os índios o pajé poderia ter autoridade superior à do cacique (BECKER, 1992, p. 45).

O prestígio dessas lideranças baseia-se principalmente nos laços de parentesco por eles estabelecidos, incluindo laços de afinidade política, bem como em sua capacidade de aglutinar por meio do cumprimento do papel de aconselhador, mediador e distribuidor de dons. Daí decorre, por exemplo, a poligamia característica das lideranças do passado. O bom líder precisava ser capaz de oferecer muitas festas e, nesses casos, ter um bom número de mulheres significava poder oferecer muita chicha 4 . 0 elevado número de mulheres também favorecia o estabelecimento de alianças, já que muitas parentelas se aliavam politicamente por intermédio de casamentos (BECKER, 1992).

Antonio Brand (1997) relatou a forma com que o indígena Feliciano Gonçalves descreveu o modelo de liderança anterior ao impacto da colonização no sul do atual Mato Grosso do Sul:

[...] tinha às vezes cinqüenta, oitenta, cem naquela localidade (...) só os parentage, é combina mais bem (...) por que tem aquele próprio cacique (...) os cacique falava aquilo e falou aquilo e acabou. [...] tinha sessenta, tinha cem, tinha cento e pouco, só grupo de família ali e todos obedecia aquele mais velho, o cacique. É o tronco, né (BRAND, 1997, p. 230-231).

O relato acima se distancia em cerca de quatro séculos das fontes analisadas por Becker, mas apresenta algo muito próximo daqueles. É

\footnotetext{
${ }^{4}$ Bebida tradicional feita com milho fermentado, cujo preparo é atribuído às mulheres.
} 
importante registrar que para os Kaiowá e Guarani contemporâneos o termo "cacique" foi apropriado, mas não para designar a liderança que tem caráter exclusivamente civil ou político. "Cacique" normalmente é um idoso, líder de parentela - hi'u ou tamõi - e importante rezador (pajé, xamã). O cacique rezador, dependendo de seu prestígio, que é maior tanto quanto são reconhecidas suas habilidades de intermediação entre o mundo dos homens e o das divindades, exerce também forte liderança política, a qual nem sempre se expressa para fora do grupo, mas é fundamental para a organização interna. Tal característica fica bem clara quando Feliciano se refere ao cacique como "tronco", numa metáfora em que o cacique é o sustentáculo do grupo, cujos membros são implicitamente representados como os galhos de uma árvore que será mais ou menos firme a depender da higidez do seu tronco.

A coesão desses grupos não era, nem tampouco é no presente, permanente. Há a possibilidade do surgimento de novas lideranças. Além disso, as alianças políticas podem ser perdidas ou enfraquecidas por várias razões. Isso possibilita ou mesmo requer o surgimento de novos tekoha ou o deslocamento de uma parentela de um para outro tekoha.

Segundo Levi Marques Pereira, um novo líder se constrói,

[...] ao longo de uma existência exemplar, baseada no carisma, na capacidade de convencimento, na capacidade de resolução de dificuldades surgidas na convivência e no acúmulo de demonstrações de habilidade para realizar os grandes ajuntamentos de caráter político e religioso. Assim, o ciclo de desenvolvimento da rede segue a trajetória de seu articulador, com ele nasce, cresce e tende a desaparecer com sua morte. Fragmentando-se, tende a ser reconstituída pela emergência de novos líderes, no mesmo local ou em outro (PEREIRA, 2004, p. 222).

Com o processo de transferência compulsória da população indígena para o interior das reservas e a limitação do espaço nas poucas áreas tradicionais mantidas, essas configurações sociopolíticas não deixaram de existir. No entanto, tiveram sua territorialidade desconsiderada e desarticulada, foram obrigadas a conviver em exíguos espaços. Esse fato teve como consequência inevitável a sobreposição de 
lideranças de parentelas, o que até hoje gera constantes tensões. Para agravar ainda mais a situação, o Serviço de Proteção ao Índio instituiu a figura do "capitão" como única liderança formalmente reconhecida pelo órgão indigenista oficial, instituiu também, ainda que sem clara intenção, a disputa interna por essa posição, o que de tempos em tempos potencializa os conflitos.

Tão logo foram demarcadas as primeiras reservas, a figura do capitão foi instituída pelo SPI. Para o SPI e sua sucessora, a Fundação Nacional do Índio (Funai), a função do capitão era a de articular, coordenar e controlar o conjunto da população de cada reserva indígena. O capitão era escolhido arbitrariamente pelos agentes do Estado e investido de autoridade perante os moradores de cada reserva indígena. Ele gozava, inclusive, de poder coercitivo, muitas vezes materializado nas temidas polícias indígenas. Ainda hoje, mesmo sem obter muito sucesso, alguns capitães tentam colocar esse mecanismo em prática (BRAND, 2004).

O antropólogo Eduardo Galvão, que foi estagiário na Divisão de Antropologia do Museu Nacional, esteve, juntamente com Virgínia e James Watson, entre os Kaiowá da Reserva Indígena Taquaperi, atual município de Coronel Sapucaia - MS, entre julho e novembro de 1943, quando a população por ele registrada era de apenas 175 indivíduos 5 . $\mathrm{Na}$ ocasião, escreveu um caderno de campo que posteriormente veio a ser publicado pela Universidade Federal do Rio de Janeiro em coedição com o Museu do Índio/Funai. O antropólogo registrou tensões e disputas, além da interferência direta do SPI na escolha do capitão (GALVÃO, 1996).

Em um sábado, um grupo de aproximadamente cinquenta indígenas, acompanhado do encarregado do SPI, saiu da reserva para fazer compras. Os índios compraram quinze barras de sabão e dez quilos de sal; depois disso, o encarregado do SPI permitiu que eles comprassem dezoito garrafas de pinga e ordenou que os indígenas fossem beber no mato, longe do grupo de pesquisadores. Curiosamente, Galvão registra que o funcionário do SPI já estava "meio embriagado" quando fez estas recomendações (GALVÃO, 1996, p. 209-

\footnotetext{
${ }^{5}$ Em 2010 a população de Taquaperi era de aproximadamente 3.180 indivíduos (CAVALCANTE, 2013, p. 89).
} 
210).

Algum tempo depois, houve uma violenta briga envolvendo um indígena contra o capitão Cândido. O motivo da briga teria sido porque o capitão, ao distribuir o sabão, o sal e a pinga adquiridos, guardou a maior parte para si, gerando insatisfação que terminou em violenta troca de agressões físicas.

Logo após o fato, os indígenas procuraram o grupo de antropólogos a quem solicitaram uma solução para a questão. Desejavam que um novo capitão fosse escolhido. O registro etnográfico demonstra que já havia uma série de intrigas e disputas internas pela capitania, inclusive permeadas por preferências do encarregado do SPI.

Cândido, enfraquecido e desacreditado como capitão, pediu permissão para trabalhar em um erval fora da reserva indígena; segundo o relato, ele temia outras represálias. Watson (1952, p. 91), ao relatar o caso, acrescenta que o capitão deposto era muito violento, já havia assassinado uma ex-mulher, não era nativo de Taquaperi e, além disso, sua atual esposa era Guarani e não Kaiowá, elementos que o enfraqueciam socialmente, já que naquela área predominava a etnia Kaiowá. Isso demonstra que, apesar de ter o poder conferido pelo SPI, o capitão não conseguia se manter a não ser que fosse capaz de aglutinar apoios entre os outros indígenas. Os antropólogos indicaram um substituto temporário, que, no entanto, posteriormente não foi confirmado pela autoridade do SPI.

Dayen chegou hoje. Sua chegada deveria resolver a questão da indicação do capitão. Dayen não aceitou Venâncio, por nós indicado, provisoriamente, no cargo. Dayen o considera demasiado "safado" e "turbulento" para o cargo. Acredita que Aparício, Justino, Risquim e Venâncio estão no mesmo nível. Para ele, Cândido seria melhor, porém fizemos por impor a nossa vontade. Cândido é realmente mal querido, partindo na preferência para capitão, por parte de Alberto, por alguma razão que ainda não descobrimos qual. A razão alegada tem sido sempre a de que "ele fez esse povo produzir - com Venâncio ou qualquer outro, ficariam eternamente a vagabundear e a passar os dias cantando à Ñandejara". Cândido acabou com esse estado de coisas. Sua função não era, ao que nos parece, a de capitão, mas, sim, a de capataz (GALVÃO, 1996 , p. 211). 
Dayen Pereira dos Santos era o agente do Posto Indígena Benjamin Constant, sediado na Reserva Indígena de Amambai. Sua chegada na condição de autoridade do SPI foi vista por Galvão como a possibilidade de solução para a questão, pois, no entendimento da época, cabia ao órgão tutelar a indicação do capitão. Percebe-se que o SPI, representado por Dayen e Alberto (encarregado da reserva indígena), preferia manter o capitão deposto, o que não aconteceu, porque a situação política dele era insustentável. Essa preferência demonstra que o capitão era a figura indígena responsável por impor aos demais a ordem necessária para que os ideais assimilacionistas da política indigenista oficial pudessem ser postos em prática. Em momento algum, nem mesmo pelos antropólogos presentes, foi levantada a hipótese de se nomear um capitão com base em critérios próprios de escolha do grupo indígena, o que também não seria fácil, pois havia clara divisão naquele pequeno coletivo.

Apesar da extrema interferência, tanto a nomeação quanto a permanência de alguém como capitão dependia e ainda depende da capacidade de aglutinação do escolhido. Ou seja, embora o SPI desejasse usurpar do grupo indígena o poder de suas decisões políticas, não conseguia fazê-lo totalmente, conforme indica a passagem a seguir:

Dayen reuniu a indiada hoje, para comunicar-lhes a escolha do novo capitão. Decidiu não nomear ninguém, mas, indicou Pedro como sargento. Houve um zun zun zun, por parte do grupo que ladeava Venâncio. Pedro disse que não queria ser sargento, porque não iriam obedecê-lo, e ele seria obrigado a meter o facão em um, e outro iria matá-lo.

Queria o apoio de Alberto ou de Mário, para agir. Pedro seria, naturalmente, um segundo Cândido, já foi capataz num erval e é forte o suficiente para impor-se. No final, decidiram que não mais haveria nem capitão, nem sargento, nem coisa alguma. Todos seriam iguais, devendo cada um cuidar de sua família. Isso pareceu satisfazê-los. Ficou também anotado que caberia a nós qualquer decisão, eles acatariam, tanto se tratando de trabalho fora, como contas e etc. Estamos assim, além de antropólogos, encarregados de fato (GALVÃO, 1996, p. 211). 
$\mathrm{Na}$ ausência de um nome que satisfizesse o agente do SPI e encontrasse apoio entre os indígenas, optou-se pela indicação de um indígena como sargento, posição que seria equivalente à de auxiliar do capitão. $O$ indicado, no entanto, percebendo a fragilidade de sua situação, preferiu não aceitar a incumbência. Apesar de no final das contas não terem decidido sobre um novo capitão, a autoridade formal na reserva continuou nas mãos do SPI, que momentaneamente passou a ser personificado na figura dos antropólogos que ali estavam (WATSON, 1952, p. 91).

Somente há pouquíssimo tempo a Funai deixou de interferir na escolha de capitães. O telex $n^{\circ} 94$, de 9 de outubro de 1990, orientou os servidores da fundação a não mais interferir na escolha de capitães (BRAND, 2004, p. 233). Em 15 de maio de 2008, o presidente da Funai assinou a Portaria $n^{\circ} 491$, que versa principalmente sobre segurança pública em terras indígenas. Tal portaria também é considerada como a definitiva proibição da interferência do órgão indigenista na escolha de lideranças indígenas na região de ocupação tradicional kaiowá e guarani. Segundo ela:

\begin{abstract}
Art. 10 A AER [Administração Executiva Regional] Cone Sul deve dar publicidade ao fato de que a liderança indígena denominada "Capitão" goza da mesma autoridade que outras lideranças, sendo que todas as lideranças gozam da mesma legitimidade junto às comunidades. Esse relevante detalhe deve ser enfatizado, não apenas aos agentes de segurança, mas também a todo e qualquer agente público e privado que atue em terras indígenas.

Parágrafo único. Deve-se dar publicidade ao fato de que a FUNAI não emite qualquer documento reconhecendo lideranças ou capitães. As antigas carteirinhas plastificadas denominadas de "Portaria de Capitão" não gozam de efeito legal.
\end{abstract}

Apesar da postura oficial do órgão, são frequentes os relatos de indígenas que indicam que ainda há pouco tempo alguns servidores se envolviam em questões de política interna das terras indígenas. Alguns ainda hoje acusam servidores de tais intervenções. Na verdade, além de boa-fé, o agente público precisa ter muita habilidade para não sofrer essas acusações, atitudes despropositadas podem ser interpretadas 
como apoio a um ou outro grupo. A simples presença em uma reunião onde se pretende substituir um capitão quase sempre é interpretada como uma forma de apoio ao grupo que a ele se opõe.

Com frequência ocorrem eleições de capitães, tais atos não têm regra muito rígida, em alguns casos participam apenas os apoiadores de um dos pretendentes ao cargo, sendo que ele, todavia, pretende impor a sua autoridade a todo o grupo. Após a realização dessas reuniões, os novos capitães se dirigem à Funai e a outros órgãos públicos buscando o reconhecimento destes. Ainda hoje solicitam a chamada portaria de capitão. Geralmente são esclarecidos tal como manda a Portaria $n^{\circ} 491$, mas nem sempre se dão por satisfeitos. Certa vez, numa terra indígena 6 assistida pela Coordenação Regional de Ponta Porã, um destes capitães reproduziu a cópia do protocolo que fez junto à Funai da ata que o elegeu e distribuiu por toda a terra indígena afirmando ser a sua portaria de capitão, o que gerou grande transtorno interno, bem como para a coordenação regional da Funai, que foi vista como politicamente parcial por uma parte daquela população.

Durante o período em que atuei como indigenista especializado na Funai (2011-2013), observei diversos resquícios do arbitrário papel de definidor de lideranças indígenas que o órgão indigenista oficial exerceu. Naquele período, participei de diversas mediações de conflitos entre lideranças indígenas. Nessas ocasiões, percebi que muitos esperavam que atuássemos como uma espécie de magistrado, que decidíssemos quem estava com a razão e, portanto, quem tinha legitimidade para exercer a liderança em determinada terra indígena. Quando argumentava que a Funai não exerce mais o papel de definidor de capitães e que estávamos ali apenas para acompanhar o processo interno de negociações e ajudar na mediação, eram notáveis as reações de descontentamento. Foram frequentes, inclusive, as exclamações em tom ameaçador do tipo: "hoje o doutor tem que resolver isso, se não ninguém sai daqui”. A tarefa de mediador era muito inglória, pois,

\footnotetext{
${ }^{6}$ Terra indígena é um conceito jurídico inserido na legislação brasileira por meio da Lei no 6.001/1973 e definido no ordenamento constitucional no Art. 231 da Constituição Federal de 1988. Segundo a Constituição, trata-se de terra de ocupação tradicional indígena, sobre a qual os indígenas detêm direito congênito, imprescritível e inalienável. Ao Estado cabe o ato de reconhecê-las, demarcá-las e protegê-las. Sendo assim, em tese, todas as áreas de ocupação tradicional indígena podem ser classificadas como terras indígenas, entretanto, ainda há centenas de reivindicações indígenas que não foram objeto de estudos e de efetiva demarcação pelo Estado brasileiro (ver: CAVALCANTE, 2013, p. 43-57).
} 
organizados em parentelas, raramente os Kaiowá ou Guarani mantinham um acordo por muito tempo.

Em regra, os acordos são temporários e podem ser desfeitos com uma rapidez inimaginável para um não indígena. Para se ter uma ideia, em 2011 um procurador da república, um antropólogo do Mistério Público Federal (MPF), uma servidora da Funai e eu participamos de uma reunião na Terra Indígena Jaguapiré, localizada no município de Tacuru - MS, onde um dos grupos sociopolíticos pretendia depor o capitão para nomear um aliado em seu lugar. A disputa era muita tensa, com acusações de ambos os lados e acusações de interferência da Funai local. Depois de um dia inteiro de negociações (sem pausa para água, almoço ou banheiro), conseguimos reunir duas comissões com representantes das facções em disputa. Depois de muita conversa, chegaram a um acordo. No entanto, antes mesmo que saíssemos da terra indígena, fomos interceptados por um dos grupos, cujos membros haviam decidido desfazer o combinado, tudo voltava à estaca inicial, permaneceu o impasse. Curiosamente, dois grupos, que nessa ocasião defendiam posições antagônicas, alguns meses depois procuraram a Funai na condição de aliados, anunciando que pretendiam promover novas mudanças na forma de exercício da liderança daquela terra indígena.

Atualmente a Funai e o MPF têm se esforçado ${ }^{7}$ para respeitar as formas próprias de organização de lideranças indígenas, não interferindo nos processos internos de escolha ou legitimação, fato ainda pouco compreendido por outros órgãos estatais. Observa-se que, mesmo nas situações mais tensas, quando não há intervenção externa a situação tende a ser resolvida pelos indígenas de maneira mais satisfatória, mas há dilemas.

Já está claro que a capitania não era uma das antigas formas tradicionais de liderança para os Guarani e Kaiowá, no entanto, tão arbitrária quanto foi a sua imposição seria hoje a sua eliminação por ato administrativo. Observa-se que em alguns locais a capitania adquiriu certa tradicionalidade ${ }^{8}$. Recentemente uma parte da população da

\footnotetext{
${ }^{7}$ Ainda que isso seja impossível, pois a relação entre a liderança e os órgãos públicos sempre acaba sendo fator de legitimação e empoderamento da mesma perante seus aliados.

${ }^{8}$ Isso não significa que não seja criticada e questionada por parcelas da população indígena.
} 
reserva indígena Limão Verde, de Amambai-MS, subscreveu uma carta, enviada a vários órgãos públicos, em defesa do capitão que estava sendo questionado por outro grupo de indígenas. Nessa carta, paradigmaticamente está escrito que a capitania é uma forma tradicional e secular de liderança guarani e kaiowá. Ainda que, por certo, a apropriação desse conceito não tenha trazido consigo os significados que Ihes são atribuídos na academia, a afirmação revela que para uma parte significativa da população daquela reserva, a figura do capitão é aquela que melhor a representa como liderança tradicional.

Outro ponto que leva a acreditar em alguns casos de tradicionalização da capitania é a dificuldade que os indígenas têm para aceitar mais de uma liderança reconhecida em cada terra indígena. Em algumas situações, afirma-se aos coletivos indígenas em disputa que é perfeitamente possível para a Funai e outros órgãos públicos atenderem e reconhecerem várias lideranças de uma mesma terra indígena, que é possível que cada liderança represente uma parcela da população, mas essa opção só é considerada quando é totalmente insustentável a manutenção de uma única liderança, seja ela na forma do capitão, de uma comissão ou de uma figura que abdique ao título de capitão e adote simplesmente o designativo de liderança.

Como o modelo da capitania se distancia do antigo modelo de escolha de lideranças pelos Guarani e Kaiowá, sua legitimidade sempre foi precariamente reconhecida pela população. Um capitão, durante o período tutelar, para se manter no poder, precisava ser eficiente naquilo que o órgão indigenista esperava, mas também perspicaz na manutenção das regras internas de distribuição de dons. Ou seja, precisava atender aos interesses das diversas parentelas residentes em uma mesma área, buscando por diversos caminhos ter um apoio ainda que mínimo dos hi'u ou tamõi.

Os habitantes das terras indígenas esperam do capitão algumas ações que seriam próprias das lideranças antigas, como o aconselhamento, por exemplo, mas o avaliam principalmente por sua habilidade em conseguir atender aos interesses dos diversos grupos familiares residentes em cada área. Sua habilidade em se relacionar com o exterior, principalmente com os órgãos de Estado e as entidades de apoio, também é constantemente avaliada (BRAND, 2004, p. 223). 
Com a instituição das reservas e a da capitania, o modelo de lideranças kaiowá e guarani se tornou mais complexo, os caciques rezadores e outros líderes de parentelas - hi'u ou tamõi - continuaram exercendo o principal papel enquanto lideranças tradicionais, no entanto, há uma disputa pelo poder político com os capitães, especialmente no que diz respeito à ocupação da terra e ao relacionamento com entidades indigenistas e órgãos governamentais. Não raramente, dessas disputas originam-se vários conflitos.

A relação do capitão com os órgãos indigenistas, inclusive os não estatais, e com poder público em geral é um dos pontos centrais de sua atuação. Todas essas instituições injetam mais ou menos recursos nas terras indígenas e a chegada desses recursos à população é, quase sempre, intermediada pelo capitão (ou outra liderança), que na prática exerce importante papel de distribuidor de dons. Nesse sentido, o reconhecimento dos órgãos indigenistas é um forte mecanismo de empoderamento dos capitães. Quase sempre são eles quem representam as comunidades em atividades exteriores, fazem várias viagens e conseguem capitalizar suas relações em forma de poder interno. Em Mato Grosso do Sul, até 2010, por exemplo, a Funai tinha por prática entregar ao capitão o quantitativo total de cestas de alimentos do programa de segurança alimentar cabível a uma determinada terra indígena. Sendo isso feito de boa-fé, esperava-se que o capitão distribuísse as cestas de maneira equânime. Obviamente, isso quase nunca ocorria, o capitão se utilizava desse recurso para se empoderar favorecendo apenas a si e aos seus aliados. Desde março de 2011, no entanto, as coordenações regionais da Funai vêm entregando as cestas de alimentos em mãos para cada família. Não há a menor dúvida de que esse sistema de distribuição é muito dispendioso e logisticamente complicado, mas é a única forma encontrada para se assegurar que todas as famílias recebam a cesta que lhes cabe. $O$ empoderamento que a entrega de cestas de alimentos ao capitão representava é comprovado pelas inúmeras reclamações e solicitações de cestas adicionais por parte destas lideranças que a instituição recebeu após a mudança de sistemática. Para eles, a perda do poder de distribuição das cestas é uma perda política, pois deixaram de ter em suas mãos uma importante moeda de troca que utilizavam com 
frequência para o estabelecimento e manutenção de alianças internas.

Muitas vezes o capitão opta por agir como uma liderança tradicional antiga, nesses casos distribui os recursos ${ }^{9}$ somente entre os membros de seu grupo familiar extenso e entre aqueles com quem tenha algum nível de aliança política. Em outros casos, consegue distribuir de maneira mais igualitária, amenizando a oposição imposta pelos outros grupos familiares ou políticos. O capitão precisa ser muito habilidoso para se manter na posição. Em analogia ao ditado popular, ele precisa agradar a gregos e a troianos. Quando opta por uma posição mais radical de distribuir somente entre os seus, é alvo de forte oposição daqueles que se sentem prejudicados. Quando os seus é que se sentem prejudicados, ele perde o apoio do grupo e, consequentemente, sua legitimidade.

Atualmente, em algumas terras indígenas, a eleição por sufrágio tem se tornado uma forma habitual de escolha de capitães. Como esse também não é um dos modelos tradicionais antigos de escolha de lideranças, tem se mostrado ineficaz na amenização dos conflitos em razão de disputa por lideranças. Salvo exceções, a ideia de um mandato por prazo fixo é completamente inoperante e o capitão consegue permanecer na posição apenas tanto quanto for capaz de manter seu prestígio e legitimidade.

Além da capitania e dos líderes religiosos, hoje se veem algumas outras formas de liderança nas terras indígenas guarani e kaiowá. A comissão de lideranças é a mais destacada. No entanto, o que se observa é que ela também não é capaz de representar a totalidade dos interesses da totalidade dos residentes em uma determinada terra indígena. Frequentemente, seus atos são questionados por grupos que se sentem preteridos no processo. A comissão é uma tentativa de democratizar a capitania, mas na essência mantém seus mesmos elementos, talvez de forma mais difusa.

Professores e outros líderes indígenas que têm projeção para além de suas comunidades também têm ocupado importantes espaços de liderança. Seu papel tem sido muito importante nos embates políticos sobre a questão da terra, assim como em outros temas de interesse

\footnotetext{
${ }^{9}$ Inclusive a indicação de nomes para cargos públicos no interior das TI's. É nevrálgica a disputa pelos cargos de professor e de agente de saúde, por exemplo.
} 
geral, como a educação, a saúde e o saneamento. Seu prestígio, no entanto, nem sempre se reverte em poder no interior das terras indígenas, mas lhes proporciona a oportunidade do estabelecimento de importantes relações exteriores. Trata-se de um fenômeno interessante, alguns indivíduos que participam de importantes comissões nacionais e até internacionais não pertencem às parentelas de maior prestígio em suas terras indígenas de origem. Sua legitimidade e reconhecimento advêm principalmente de sua capacidade de relacionamento com o mundo dos não índios e de seu posicionamento em defesa dos interesses gerais dos Guarani e Kaiowá, por isso os professores se destacam, já que o acesso à educação escolar de nível superior lhes facilita e proporciona essa atuação. Por outro lado, como a legitimidade destes nem sempre se sustenta no prestígio de sua família extensa, por vezes ocorrem problemas de representatividade. Ou seja, mandatários públicos acreditam estar falando com lideranças que representam todos os grupos kaiowá e guarani, quando, na prática, tal representação é bem mais restrita. Isso gera insatisfação em algumas lideranças de famílias extensas e de tekoha.

Muito cacique para pouca terra: a luta pela terra como expressão da organização sociopolítica guarani e kaiowá em Mato Grosso do Sul

Há um ditado popular que diz há muito cacique para pouco índio, ele é muito utilizado quando se quer dizer que existe um número muito grande de líderes para um pequeno número de liderados, o que muitas vezes é apontado como motivo de confusão ou desgoverno. $O$ trocadilho aqui proposto é de que há muito cacique para pouca terra. Pretende-se enfatizar que, nas atuais terras indígenas kaiowá e guarani em Mato Grosso do Sul, a sobreposição de lideranças, resultante da dinâmica acima apresentada, faz com que ocorram contumazes conflitos e confusões. Nesse caso, no entanto, o problema não está ligado à relação entre o número de líderes e liderados, mas sim com a exiguidade de espaços territoriais disponíveis para que essas relações sociais e de poder possam se territorializar.

A política de concentração da população indígena em reservas e 
mesmo em pequenas partes de seu território de ocupação tradicional (como as terras indígenas demarcadas no sul de Mato Grosso do Sul entre as décadas de 1980 e 2000) tem ocasionado a constante sobreposição de lideranças. Isso ocorre porque várias famílias extensas, muitas vezes inimigas entre si, são obrigadas a conviver no mesmo espaço. Além disso, como já foi argumentado, é próprio da cultura (e certamente da maioria das culturas existentes) guarani e kaiowá o surgimento de novas lideranças, nunca é demais lembrar que as culturas são dinâmicas.

Várias situações podem fazer aflorar conflitos internos entre lideranças nas terras indígenas. Além da falta de habilidade do capitão para manter sua legitimidade, isso pode ocorrer, por exemplo, como fruto de uma acusação de feitiçaria, por questões religiosas 10, ou quando uma parentela demanda por maior espaço territorial. Ademais, por várias circunstâncias, novas lideranças podem surgir e buscar ocupar um lugar de destaque político entre os indígenas de uma determinada área. É comum, ainda, que várias parentelas nunca tenham se adequado de fato ao modelo da reserva indígena, ficando politicamente sufocadas por aquelas que se tornam hegemônicas. Nessas situações, o conflito é esperado e inevitável, próprio da configuração social guarani e kaiowá. Mesmo antes do aldeamento compulsório e esbulho territorial, a emergência de novas lideranças e conflitos apensos ocorria, mas nessa época a solução era bem mais fácil. A solução mais tradicional era que uma das lideranças em confronto, geralmente a mais fraca, saia com seu grupo em busca de novo local para assentamento. Atualmente essa atitude é bem mais difícil de ser posta em prática, tanto que só ocorre em situações extremas (THOMAZ DE ALMEIDA, 2001, p. 201).

O fato é que diante do conflito, dependendo da relação de forças, uma parte sempre sai mais ou menos enfraquecida. Quando isso ocorre, a parte mais fragilizada tem algumas opções: 1) pode se resignar à condição de liderado e não mais participar de forma ativa, pelo menos temporariamente, do processo político interno; 2) pode se retirar levando consigo parte de sua parentela e se estabelecer em outra terra

\footnotetext{
${ }^{10}$ A entrada das igrejas evangélicas nas TI's provocou mais um ponto de conflito, pois muitas vezes seus membros se posicionam contrariamente às praticas da religião kaiowá.
} 
indígena onde tenha aliados, nesse caso ingressando como subalterno nos meandros do poder interno; 3) ou, como opção extrema na atualidade, pode buscar um novo lugar para assentar o seu grupo e exercer a sua liderança.

Essa última opção é sem dúvida a que despende maior esforço. Antes do reservamento, esta provavelmente seria a primeira opção. No entanto, como atualmente não há estoques territoriais disponíveis para a territorialização de novos tekoha, o esforço do líder precisa ser muito grande para convencer as pessoas a segui-lo para locais altamente precários, como margens de rodovias e acampamentos ${ }^{11}$ de retomadas, onde ficam expostos a toda sorte de violências. Todavia, em situações em que a permanência de uma parentela em uma determinada terra indígena se torna insustentável, é justamente isso que acontece.

Ou seja, a sobreposição de lideranças em situações insustentáveis dá vazão a importantes episódios de retomadas de terras indígenas observados no território de ocupação tradicional kaiowá e guarani em Mato Grosso do Sul.

Nesses movimentos de retomada, os caciques rezadores exercem um papel fundamental. Eles preparam os grupos e o ambiente para que a retomada possa ocorrer com harmonia entre os humanos e as divindades. Como guardiões da tradição, são fontes fundamentais de inspiração para que os indígenas resistam aos movimentos colonialistas de esbulho territorial. Sua presença é marcante nas retomadas e sua atuação na condução dos rituais religiosos é fundamental para a manutenção da chama da luta acesa.

Para exemplificar, apresento brevemente o caso de Panambi Lagoa Rica, localizada no município de Douradina. Essa terra indígena está localizada na região onde, na década de 1940, o governo federal resolveu instalar a Colônia Agrícola Nacional de Dourados. Apesar dos esforços da administração do empreendimento colonizador para retirar esses indígenas de suas terras de ocupação tradicional, eles

11 O termo "acampamento" é utilizado para designar alguns tipos de assentamentos indígenas oficialmente não reconhecidos como terras indígenas, podem ser tanto de caráter permanente quanto de caráter provisório, mobilizados para o empreendimento da luta pela terra. Neste trabalho, o termo se refere especialmente a frações de territórios objetos de retomadas pelos indígenas. Tais frações passam a ser ocupadas em absoluta precariedade material e jurídica. As retomadas são utilizadas como mecanismo de pressão para que o governo acelere os processos administrativos de reconhecimento dessas terras indígenas (Ver: CAVALCANTE, 2013, p. 106-112). 
conseguiram permanecer no local, habitando uma área pouco superior a 300 ha. Nas décadas de 1970 e 1980, foram realizados trabalhos com o objetivo de regularização fundiária, mas não resultaram em atos administrativos demarcatórios e/ou homologatórios. Atualmente, os indígenas reivindicam a devolução de suas terras, inclusive uma extensa parte que está em posse de colonos ou de seus sucessores. Em 2005, foi realizada uma retomada de terras vizinhas à aldeia que atualmente ocupam. Como resultado dela, conseguiram, com intermédio do MPF, que a Funai publicasse uma portaria designando um Grupo Técnico (GT) para realização dos estudos de identificação e delimitação da terra indígena. Até 2008, no entanto, os trabalhos não haviam sido finalizados, quando, novamente sob pressão, a Funai constituiu um novo GT. Em 12 de dezembro de 2011, por meio do Despacho de $n^{\circ}$ 524, a presidência da Funai identificou e delimitou a Terra Indígena Panambi - Lagoa Rica, com aproximadamente 12.196 hectares. Apesar desse avanço, os passos seguintes do processo demarcatório ainda não foram dados. Atualmente, já estão muito incomodados com a demora, os indígenas aguardam por mudanças da situação fática.

Nessa terra indígena, observou-se a existência de três grupos político-familiares de prestígio. Os principais líderes de cada um deles já exerceram a capitania. Todos os três são acusados por seus oponentes de privilegiar seus parentes e aliados na distribuição de recursos externos.

O acirramento dessa disputa ocorreu no começo dos anos 2000 e culminou no enfraquecimento de dois desses líderes. Essa situação fez com que eles, na busca de um espaço para a territorialização de seus grupos, liderassem movimentos de retomadas de terras, dando origem a dois acampamentos, o Laranjeira Ñande Ru, localizado no município de Rio Brilhante, e o Itay Ka'aguy Rusu, localizado ao lado da Terra Indígena Panambi - Lagoa Rica, no município de Douradina. Em contrapartida, o grupo que estava mais forte no interior da aldeia também realizou uma retomada, instalando o acampamento Guyra Kambiy. Além desse exemplo, outras histórias assemelhadas são encontradas na recente tese de doutorado de Aline Castilho Crespe (2015), que fez um estudo histórico e etnográfico em vários acampamentos indígenas no sul de Mato Grosso do Sul. 
Tanto as lideranças desses acampamentos quanto seus membros ainda mantêm fortes relações sociais na área de origem, mas reivindicam a demarcação de suas terras tradicionais para que suas relações sociais e econômicas possam ser devidamente alocadas de acordo com a territorialidade própria do grupo. Quanto ao exemplo citado, pode-se afirmar que, enquanto grupos e unidades sociais, os três segmentos já existiam há muito tempo e eram forçados ao convívio no interior do mesmo espaço territorial. Apesar disso, os órgãos de Estado ainda não eram capazes de lidar com a multiplicidade de unidades sociais no interior de uma pequena e aparentemente homogênea terra indígena, dando sempre mais atenção e privilégios àqueles que se sobressaíam. Nesse sentido, os movimentos de retomadas de terras, além de serem imprescindíveis para dar visibilidade aos movimentos reivindicatórios, têm importante função sociopolítica, pois viabiliza a autonomia política de diversos tekoha.

Retomar uma fração de terra de ocupação tradicional indígena dá visibilidade ao grupo e induz às entidades governamentais e não governamentais a reconhecer a sua existência. Com isso, seus líderes voltam a ser, ou passam a ser, reconhecidos e a gozar do prestígio de lideranças indígenas, sendo convidados para reuniões, ouvidos e considerados intermediários entre o exterior e suas respectivas comunidades. Na prática, transformam seu poder interno em um tipo de capital externo, o que lhes garante acesso a vários tipos de recursos. Esses líderes, evidentemente, só se sustentam por ter a capacidade de reunir um grupo em torno de si, e, ao empreender suas retomadas de terras, reproduzem o modelo antigo e tradicional de territorialização, buscando um local propício para o assentamento de sua parentela.

Curiosamente, em um seminário sobre questões fundiárias indígenas, promovido pelo Conselho Nacional de Justiça (CNJ), em Dourados, nos dias 25 e 26 de maio de 2011 , um dos ruralistas que defendia sua posição argumentou que muitas das retomadas não tinham nada de tradicional. Para ele, elas eram apenas fruto de interesses pessoais de alguns indígenas que pretendiam se tornar caciques. De fato, querendo desqualificar as retomadas, ele descreveu uma situação perfeitamente possível de ser considerada tradicional, ou seja, lideranças indígenas em situação insustentável no interior das 
minúsculas terras indígenas em que vivem precisam - assim como seus antepassados faziam - procurar outro local para assentar seus tekoha, retornam, então, para as áreas que já estiveram sob o domínio de seus antepassados.

É factível que, ao desconsiderar por completo a territorialidade indígena quando da criação das reservas, o Estado tenha criado uma série de situações de conflito que hoje, muitas vezes, desencadeiam os movimentos de retomada de terras de ocupação tradicional indígena em Mato Grosso do Sul. Numa leitura de causa e efeito, poder-se-ia dizer que no início do século XX houve um movimento coercitivo de ingresso e acomodação de unidades sociopolíticas nas reservas indígenas. Já a partir da década de 1970, o que se vê é o movimento contrário, quando essas unidades sociais saem das reservas e de pequenas terras indígenas demarcadas nos anos 1980-2000 em busca da retomada de suas terras tradicionais e, assim, da reconstituição das relações sociais baseadas nas parentelas e alianças políticas entre elas, ou seja, buscam reconstituir sua territorialidade em seus antigos tekoha (na acepção territorial do termo).

Em 2007, a Funai assinou um Compromisso de Ajustamento de Conduta junto ao MPF. Em decorrência disso, seis Grupos Técnicos foram criados com a finalidade de identificar e delimitar mais de trinta tekoha guarani e kaiowá na região sul de Mato Grosso do Sul; entretanto, por vários fatores, eles ainda não produziram nenhum efeito que proporcionasse mudanças fáticas em termos de efetiva ocupação indígena dessas terras.

Em termos conceituais, os trabalhos iniciados em 2008 inovam ao propor uma abordagem territorial da questão, antes os casos sempre foram tratados isoladamente. Em tese, seriam demarcadas grandes terras indígenas onde vários tekoha poderiam se territorializar. Com essa configuração hipotética, a movimentação de tekoha e famílias extensas seria mais livre, menos limitada pelas propriedades privadas, ou seja, ao menos em partes, aproximar-se-ia do modelo tradicional antigo de ocupação do território. Certamente esse modelo, se efetivamente empregado, contribuirá significativamente para a reprodução física, cultural e social dos Guarani e Kaiowá, tal como reza a Constituição Federal de 1988 (CAVALCANTE, 2013). 
À guisa de conclusão, é importante frisar que, embora não se deva desconsiderar fatores de ordem econômica (que hoje comporta a subsistência e pequenas necessidades monetárias), as motivações sociopolíticas ocupam lugar de maior destaque nos movimentos reivindicatórios guarani e kaiowá em Mato Grosso do Sul. Como na concepção capitalista a finalidade da terra é tão somente a exploração econômica e a consequente obtenção de lucros, numa atitude etnocêntrica muitos tentam deslegitimar as reivindicações territoriais dos indígenas, levantando o argumento de que eles não produzem nas terras de que dispõem. Tal acusação é duplamente falsa, pois, sim, eles produzem vários tipos de alimentos em suas terras, mas, sobretudo, e tão importante quanto, produzem sua cultura e suas formas de sociabilidade (CAVALCANTE, 2013).

\section{Referências bibliográficas}

BECKER, Ítala Irene Basile. Lideranças Indígenas no começo das reduções jesuíticas da província do Paraguay. Pesquisas Antropologia, São Leopoldo, n. 47, p. 01-197, 1992.

BRAND, Antonio Jacó. O confinamento e o seu impacto sobre os Pai-Kaiowá. 1993. 276 f. Dissertação (Mestrado em História) - Pontifícia Universidade Católica do Rio Grande do Sul, Porto Alegre, [1993].

O impacto da perda da terra sobre a tradição Kaiowa/Guarani: os difíceis caminhos da Palavra. 1997. 390 f. Tese (Doutorado em História) - Pontifícia Universidade Católica do Rio Grande do Sul, Porto Alegre, [1997].

Os complexos caminhos da luta pela terra entre os Kaiowá e Guarani no MS. Tellus, Campo Grande, v. 6, n. 1, p. 137-150, 2004.

BRASIL. Portaria $\mathbf{N}^{\mathbf{0}} \mathbf{2 3 2}$ do presidente da FUNAI. Constitui Grupo Técnico com a finalidade de realizar estudos complementares de identificação e delimitação da Terra Indígena Panambi (Arquivo da Procuradoria da República no Município de DouradosMS - Inquérito Civil Público Nº 1.21.001.000290/2005-19, fl. 376), 2005.

Portaria No 491 do presidente da FUNAI, de 15/05/2008. Publicada na Separata do Boletim de Serviço da FUNAI, ano XXI, nº 09-11, maio / junho de 2008, de 06/06/2008. p. 5-6. 
- Despacho $\mathbf{N}^{\circ} 524$ de 9 de dezembro de 2011. Aprova o Relatório Circunstanciado de Identificação e Delimitação da Terra Indígena Panambi - Lagoa Rica. Publicado no Diário Oficial da União No 237 de 12 de dezembro de 2011. p. 166169.

CAVAlCANTE, Thiago Leandro Vieira. Tomé: o apóstolo da América. Índios e Jesuítas em uma história de apropriações e ressignificações. Dourados: Ed. UFGD, 2009.

Colonialismo, território e territorialidade: a luta pela terra dos Guarani e Kaiowa em Mato Grosso do Sul. 2013. 470 f. Tese (Doutorado em História) - Faculdade de Ciências e Letras de Assis, Universidade Estadual Paulista, [2013].

CRESPE, Aline Castilho. Mobilidade e temporalidade entre os Guarani e Kaiowa no Mato Grosso do Sul. 2015. Tese (Doutorado em História) - Universidade Federal da Grande Dourados, Dourados, [2015].

DHESCA, Plataforma. Plataforma de Direitos Humanos. Violação de Direitos Humanos dos Indígenas no Estado do Mato Grosso do Sul. Curitiba: Plataforma Dhesca, 2014.

EREMITES DE OLIVEIRA, Jorge; PEREIRA, Levi. Ñande Ru Marangatu: Laudo antropológico e histórico sobre uma terra kaiowa na fronteira do Brasil com o Paraguai, município de Antônio João, Mato Grosso do Sul. Dourados: Editora UFGD, 2009.

GALVÃO, Eduardo. Diários de Campo entre os Tenetehara, Kaioá e Índios do Xingu. Rio de Janeiro: Editora UFRJ/Museu do Índio/FUNAI, 1996.

PEREIRA, Levi Marques. Imagens kaiowá do sistema social e seu entorno. 2004. 345 f. Tese (Doutorado em Antropologia Social) - Universidade de São Paulo, São Paulo, [2004].

SUSNIK, Branislava. Los aborigenes del Paraguay II: Etnohistoria de los Guaranies. Epoca colonial. Asuncion: Museo Etnografico “Andres Barbero”, 1979-1980.

THOMAZ DE ALMEIDA, Rubem Ferreira. Do desenvolvimento comunitário à mobilização política: o Projeto Kaiowa-Ñandeva como experiência antropológica. Rio de Janeiro: Contra Capa Livraria, 2001.

WATSON, James B. Cayuá Culture Change: A Study in Acculturation and Methodology. American Anthropologist, New York, v. 54, n. 2, p. 1-149, 1952.

Recebido em: 22/03/2015* Aprovado em: 05/06/2015 * Publicado em: 30/06/2015 
CAVALCANTE - Lideranças indígenas e a luta pela terra como expressão da organização...

Espaço Ameríndio, Porto Alegre, v. 9, n. 1, p. 182-205, jan./jun. 2015. 